\title{
IMPACT OF METHIONINE AND BETAINE OR BOTH ON THE PERFORMANCE OF BROILERS FED LOW PROTEIN DIETS: 2- BONE MEASUREMENTS, BLOOD PARAMETERS AND HISTOLOGICAL EXAMINATION
}

\author{
Nematallah G.M. Ali ${ }^{1}$; A.I.El-Faham ${ }^{1}$; Tork M. Dorra ${ }^{2}$ and M.S. Hassanien ${ }^{1}$ \\ ${ }^{1}$ Dept. of Poult. Prod., Fac. of Agric., Ain Shams Univ., Egypt. \\ ${ }^{2}$ Dept. of Poult. Prod., Fac. of Agric., Mansoura Univ., Egypt.
}

\section{SUMMARY}

$\mathrm{T}$ This study aimed to examine the effect of methionine and/or betaine supplementation on bone measurements, some blood parameters, fatty acid differentiation and histological examination of broilers that fed low protein diets. A total numbers of 180 one day old unsexed Hubbard boiler chicks were divided into six treatments (30 birds each). Each treatment contained 3 replicates of 10 birds. Two levels of dietary crude protein (recommended $\left.\mathrm{D}_{1}\right)$ control diet, and $2 \%$ crude protein $\left(\mathrm{D}_{2}\right)$, treatment diets $\left(\mathrm{T}_{1}-\mathrm{T}_{5}\right)$ and DL-methionine (MET), or betaine (BET), were added in experimental treatment diets as follows:

1-Control; Chicks were fed control diet $\left(\mathrm{D}_{1}\right)$

2-T1: Chicks were fed low protein diet, $2 \%$ crude protein $\left(\mathrm{D}_{2}\right)$

3-T2: Chicks were fed D2 + 100\% MET

4-T3: Chicks were fed D2 $+50 \%$ MET $+50 \%$ BET

5-T4: Chicks were fed D2 + 25\% MET + 75\% BET

6-T5: Chicks were fed D2 + 100\% BET

All diets (control and $\mathrm{T}_{1-5}$ ) were equal in lysine $\%$ and MET add in the $\mathrm{T}_{2}$ diet up to control diet.

The results indicated that:

1- Tibia length was significantly affected by treatments and chicks fed $\left(\mathrm{T}_{2}\right)$ diet gave the lowest significant values compared with control group.

2- Blood parameters showed insignificant figures in most parameters. However, AST activity had significant different and the best values were for chicks that fed on $\mathrm{T}_{4}$ compared to other treatments and control.

3- The saturation to unsaturation ratios were improved by betaine and methionine supplementation compared to control group.

4- Liver histology showed improvement for birds that fed betaine and methionine compared with control group.

It could be concluded that betaine and methionine have improved bird's health without any adverse effect on liver and these results obviously clear by blood determination. Therefore, MET and BET supplementation has been recommended in low-protein broiler diets without any adverse effect on bird's health.

Keywords: Bone measurements, MET, BET, AST. Sat. /unsat. ratios and liver histology.

\section{INTRODUCTION}

The results of many previous reports demonstrated that chicks which had received low-CP corn soybean meal diets fortified with AA,s performed equally well as those which had received the positive control diet, Holsheimeret al. (1992) and Sinovaet al. (2010).

However, due to technological advances some essentials amino acids [methionine, lysine, threonine and tryptophan] have become economically available in recent years and there is a good possibility that others will be commercially available in the future. Recent reports indicated that promising results can be obtained by the use of low-protein, amino acid supplemented diets for laying hens (Keshavaraz and Austic, 2004).

DL- methionine is normally considered to be the first limiting amino acid in poultry diets. In general, amino acid balance and nitrogen retention are improved by methionine supplementation. Hassan et al.(2003) using Mandara and Abdalla (2005) using Gimmizah found insignificant difference on final body weight by increasing dietary methionine level in their diets. Hassan et al. (2003) observed that increase daily intake of methionine was accompanied by significant improvement in egg production and 
feed conversion. Centenary, Abdallaet al. (2005) showed the opposite result.Naulia and Singh (2002) found that using different levels of methionine significantly improved digestibility coefficient of organic matter, crude protein. On the other hand, El-Husseiny et al. (2005) observed that DL- methionine supplementation had no significant effect on digestibility coefficient values of nutrients.

Betaine, the common term is a naturally occurring amino acid derivative found in a variety of feedstuffs of plant and animal origin. Betaine has two primary metabolic roles: it is a methyl group donor and it is an osmolyte that assists in cellular water homeostasis (Petronineet al., 1992).

Furthermore, betaine promotes intestinal microbes against osmotic variations and improves microbial fermentation activity, which in turn, may enhance nutrient digestibility (Ratriyantoet al., 2009).

Bone is a dynamic tissue influenced by physiological, nutritional, and physiological factors such as mechanical stress and physical activities. Overall, the economic cost associated with bone problems in poultry can add up to several hundred million dollars a year, Rathet al. (2000). In adult birds, supplementing diets with vit.D, Ca, P, phytase, Vit C, and Vit. K as well as protein energy enrichment diets, may be beneficial in maintaining bone mass and thereby, bone strength. Because bone formation is an early event related to growth, nutritional interventions directed towards producing better bone mass may be helpful.

Therefore, the aim of this study was to investigate the effect of methionine and/or betaine supplementation in the low-protein diets on the some physiological parameters, bone measurements, fatty acids differentiation of the breast meat, and liver histology of broiler chickens.

\section{MATERIALS AND METHODS}

The Present experiment was carried out at the poultry experimental unit, Agricultural experiment and Research Station at Shalakan, Faculty of Agriculture, Ain Shams University.

\section{Birds, diets and management:}

A total numbers of 180 one-day old unsexed Habbard broiler chicks were divided into six treatments (30 birds each), each treatment contained 3 replicates of 10 birds each. Chicks were reared in an environmentally controlled roomwith a continuous light and fans for ventilation and were fed starter diet from 0 to 3 weeks of age and grower diet from 4 weeks of age to the end of the experiment at 5 weeks of age (corn-soy bean meal diet). Feed and water were supplied ad libitum. Two levels of dietary crude protein (Recommended $\left(\mathrm{D}_{1}\right)$ control diet and $-2 \%$ crude proteins, treatment diets (T1-T5) and DLMethionine (MET) or Betaine (BET) were added in experimental treatment diet as follows:

1- Chicks were fed the control diet $\left(D_{1}\right)$

(Control).

2- Chicks were fed $-2 \%$ crude protein $\left(\mathrm{D}_{2}\right) \quad\left(\mathrm{T}_{1}\right)$.

3- Chicks were fed $\mathrm{D}_{2}+100 \%$ MET $\quad\left(\mathrm{T}_{2}\right)$

4- Chicks were fed $\mathrm{D}_{2}+50 \%$ MET $+50 \%$ BET $\quad\left(\mathrm{T}_{3}\right)$

5- Chicks were fed $\mathrm{D}_{2}+25 \%$ MET $+75 \%$ BET $\quad\left(\mathrm{T}_{4}\right)$

6- Chicks were fed $\mathrm{D}_{2}+100 \%$ BET

The added MET up to control diets in the T2 (0.20 and 0.12$)$ diets was partially (50\% and $75 \%)$ or completely (100\%) replaced by BET in diets $\mathrm{T}_{3}, \mathrm{~T}_{4}$ and $\mathrm{T}_{5}$. All diets (control and $\mathrm{T}_{2}-\mathrm{T}_{5}$ ) were equal in lysine \%. BET was added as 97\% - dry crystalline Betafin BT. Composition and calculated analysis of the experimental diets are presented in Table 1.

The vaccination program adopted according to standard commercial guidelines.

\section{Blood parameters:}

Individual blood samples were collected in dry clean centrifuge tubes from the slaughtered birds and plasma was separated by centrifugation at $3000 \mathrm{rpm}$ for $15 \mathrm{~min}$. and assigned for subsequent determination. Plasma samples were stored at $\left(-20^{\circ} \mathrm{C}\right)$ in a deep freezer until the time of chemical determination. Biochemical analyses of blood plasma were conducted in poultry physiology laboratory, Faculty of Agriculture, Ain Shams University. Quantitative determination of blood was included the following: total protein, albumin, globulin [determined by subtraction the value of albumen for the sample from its corresponding value for total protein], total lipid, triglycerides, total cholesterol, uric acid, AST, and ALT. All biochemical parameters of blood were calorimetrically determined using commercial diagnosing kits [Produced by Bio-Diagnostics Company, Egypt].

Bone measurements: 
Right tibia were removed and cleaned from soft tissues, then weighed and length, width of each was measured using caliper to the nearest $\mathrm{mm}$. The tibia were dried $\left(105^{\circ} \mathrm{c}\right.$ for $3 \mathrm{hrs}$.), weighed and tibia Seedor Index were calculated according to Seedor et al. (1991).

\section{Fatty acids analysis:}

Fatty acid methyl ester (FAME) was prepared by using sulfuric acid in methanol as esterifying reagent (AOAC, 1965). The FAME was analyzed by using gas chromatography (GC) Mode, Shimadzu 4c/ (PFE) equipped with FID detector and glass column $2.5 \times 3 \mathrm{~mm}$. The calibration and identification of fatty acid peaks was carried out by comparison with retention times of known authentic standards. The fatty acid results are expressed as weight percentages.

\section{Histological examination:}

During slaughtering time, 3 birds of each treatment were taken for histological studies. Liver samples were taken, immediately fixed in $10 \%$ buffered formalin solution for histological technique. All sections (4-5 $\mu \mathrm{m}$ tick) were stained with haemotoxylline and eosin (H \& E) stain according to Bancroft et al. (1994) sections were examined under light microscope and then photographed using computerized program.

\section{Statistical analysis:}

Data were statistically analyzed according to ANOVA procedures of SAS (SAS Institute, 2002). Means differences were compared using Duncan's Multiple Range Test (Duncan, 1955).

\section{RESULTS AND DISCUSSION}

\section{Bone Measurements:}

Data for some bone measurements are summarized in Table (2). Experimental treatments with BET $\left(\mathrm{T}_{3-5}\right)$ had no significant effect on studied parameters compared with control. The corresponding values for wet tibia weight $(\mathrm{g})$ ranged between 9.54 and 10.64, Tibia length $(\mathrm{mm})$ ranged between 8.30 and 8.53 $(\mathrm{mm})$ and Tibia seedor index $(\mathrm{SI})$ ranged between 0.59 and 0.62 .

On the other hand, the chicks fed $\mathrm{T}_{2}$ diet gave the lowest figures of $9.37 \mathrm{~g}, 7.93 \mathrm{~mm}$ and 0.59 for tibia weight, tibia length and SI and the differences were significant $(\mathrm{P}<0.05)$ compared with control group in tibia length only.

It is appropriate to consider that through strategic nutritional manipulations, it may be possible to increase or preserve bone mass and to maintain bone strength. Exploring the nutritional requirements that would improve collagen crosslinks may be useful in improving bone quality in meat type poultry, Rath, et al. (2000).

These results have indicated that betaine and methionine may be having important role on $\mathrm{Ca}$ metabolism, but it could not say that without more investigation on this side.

\section{Blood parameters:}

The results concerning on the effect of different treatments on some blood parameters are shown in Table (3).

Although all of blood parameters have not significant different affected by different dietary treatments, AST activity has significantly different $(\mathrm{P}<0.05)$, and the lowest value was for chicks that fed on $\mathrm{T}_{4}$ compared to other treatments and control.

Concerning of total protein, albumin, globulin, and $\mathrm{A} / \mathrm{G}$ ratio were not significantly affected by dietary treatments, but numerically $\mathrm{T}_{2}, \mathrm{~T}_{3}$ and $\mathrm{T}_{4}$ for plasma albumin have the highest values compared to other treatments and control group. Also, globulin level for chicks that fed $\mathrm{T}_{4}$ was the lowest values compared to control and other treatments. On the other hand, $\mathrm{T}_{1}$ and $\mathrm{T}_{3}$ have the lowest values for the $\mathrm{A} / \mathrm{G}$ ratio compared to other treatments. That's means methionine and betainesupplementations have an important in improving resistance to stress as well as the immune function (Zulkifliet al., 2004). These results are in agreement with those obtained by Zhan (2001) who reported that betafin [betaine] addition significantly improved the immune response and alleviated the response of body temperature.

This finding was similar to those obtained by Park et al, (2006) and Tollbaet al (2008) who reported that concentration of plasma total protein and albumin as well as globulin were not significantly affected in layers fed diets supplemented with betaine for 16 weeks under hot climate stress. Also, the same results 
were reported by Bunchasaket al. (2005) and Attiaet al. (2005), but contrary to our results, El-Ganzory et al (2004) found that methionine supplementation increased serum albumin.

Concerning kidney function, uric acid concentrations were not significantly different affected by different treatments, but numerically $\mathrm{T}_{4}$, and $\mathrm{T}_{5}$ have the highest values compared with other treatments and control groups and these results reflected that betaine and methionine supplementation have been affected on the protein metabolism and consequently increased kidney excretion.

Lipid metabolism was measured to investigate the effect of different treatments on lipid profile in broiler. Table (3) indicated that there were not significant different among different treatments and control, but numerically $\mathrm{T}_{4}$ has the lowest values for total lipid, triglycerides, and cholesterol compared to other treatments. Also $T_{2}$ and $T_{5}$ have the lowest values for cholesterol concentration. These results indicated that betaine and methionine have caused reduction in plasma total lipids, triglycerides, and total cholesterol. That's mean, methyl donor treatments regulate lipid metabolism in chickens. This reduction in plasma lipids could be due to the ability of methyl donor to reduce the transcription of lipogensis genes especially fatty acid synthase as mentioned by Xing et al., (2011). The inhibition of lipid biosynthesis in plasma and adipose tissues explained the reduction of abdominal fats and improvement of feed conversion ratio of chickens. At the same findings, Rudolph et al., (2007) indicated that methyl donor compounds especially betaine regulate lipid metabolism via regulation of transcription of fatty acid synthesis genes.

Regarding liver function, as fore mentioned AST activity has significantly different as affected by different treatments and the lowest value which for birds that fed on $T_{4}$ and these results indicated that betaine and methionine supplementation have improved of liver function,although ALT activity was not significantly different among different treatments.Methionine and betaine supplementation have improvement in liver function especially for broilers that fed on $\mathrm{T}_{2}$ and $\mathrm{T}_{5}$ which recorded the lowest values.

These treatments have important effect on reduction of liver enzymes in plasma. It could be contributed to their ability strengthen the hepatocellular membrane by its membrane.

Stabilizing action or to a counter action of free radicals by their antioxidant property (Ganesanet al., 2010). Also, betaine could induce antioxidant defensive enzyme which reduce lipid peroxidation of hepatocyte membrane and reduce the leakage of liver enzymes to plasma. These results in close to Koncaet al. (2008) and Zayed(2012) who reported that liver enzymes AST and ALT were insignificantly decreased due to betainesupplementation to turkey diet.

In conclusion, reducing of nitrogen in broiler chickens with supplementation of betaine and essentials amino acid [methionine] could play a significant role in reducing of nitrogen pollution from poultry manure. Therefore, reducing dietary protein level in the diet is a good strategy to lower ammonia emissions from broiler chickens excreta and improving environmental condition around the birds. So, we may be fed a broiler chick low protein diet with betaine and methionine supplementation without adverse effect on performance, health and improvement in economic efficiency.

\section{Effect of different treatments on breast meat fatty acid differentiation:}

Table (4) showed the effect of different treatments on saturated and unsaturated fatty acids. The data indicated that betaine and methionine supplementation have increased the C18.1, C18.2 and C18.3 concentrations compared with other treatments and control group and this increasing very clear especially in C18.1 [Oleic acid]. Also, the saturated to unsaturated ratio was improved by betaine and methionine supplementation compared with control group. These results indicated that methionine and betaine may interact with lipid metabolism by stimulating the oxidative catabolism of fatty acid via its role in carnithine synthesis. Thus offering a potential for reduced carcass fatness in commercial production and that is benefit for chickens and consequently human's health.

\section{Histological examinations:}

From Fig. 1 to Fig. 11 indicated the effect of different treatments on liver.Histopathological examination of liver from different group revealed:

\section{Control:}

Liver showed moderate to severe degenerative and necrobiotic changes of hepatocytes (Fig.1) resulting in distortion and disorganization of hepatic cords and sinusoidal dilatation (Fig. 2).

Multifocal areas of hepatic necrosis of variable size with replacement of the necrotic tissue by mononuclear cells were commonly found scattered throughout the hepatic tissue (Fig. $3 \& 4$ ).

Portal fibroplasia and dilatation of portal blood vessels associated with cholangitis and intense mononuclear cell infiltration of the bile duct wall were commonly observed (Fig. $5 \& 6$ ). 
$T_{2} \& T_{3}:$

Less severe and less extensive were noticed. In addition, Paracentral mononuclear cell infiltration (Fig. 7) and cholangitis with dilatation of portal blood vessels (Fig. 8) were observed.

$T_{4}$ :

Liver of such group revealed moderate necrobiotic changes, congestion of portal blood vessels, distortion of hepatic cords and sinusoidal dilatation (Fig. 9) associated with foci of hepatic necrosis with replacement of the necrotic cells by mononuclear cells scattered throughout the hepatic tissue (Fig. 10).

$T_{5}$ :

Liver showed diffuse vacuolar degeneration of hepatocytes (Fig. 11). In general,histological observations support the performance where growth performance of treatment groups have significantly improved without any adverse effects on liver histology and these results obviously clear in blood parameters determination.

\section{REFERENCES}

Abdalla, A.; H.M. Yakout and M.M. Khalifah (2005).Determination of lysine and methionine requirements of Gimmizah strain during egg production stage. $3^{\text {rd }}$ Inter. Poult. Con. 4-7 Apr. 2005. Hurghada. Egypt.

Attia, Y.A.; R.A. Hassan; M.H. Shehatta and S.B. Abdel-hady (2005).Growth, carcass quality and serum constitutents of slow growing chicks as affected by betaine to diets containing 2-Different levels of methionine.Inte. J. Poult. Sci., 4:856-865.

Bunchasak, C.; K. Poosuwan and R. Nukraew (2005).Effect of dietary protein on egg production and immunity responses of laying hens during peak production period. Inter. J. Poult. Sci., 4:701-708.

Duncan, D.B. (1955). Multiple Range and multiple F-test. Biometrics, 11:1-42.

El-Ganzory E.H.; R.A. Hassan and Kout El-Kloub M.E. Moustafa (2004).Effect of betaine and/or sodium sulphate supplementation as a substitute for methionine in chick diets. Egypt. Poult. Sci., 24:823-843.

Ganesan, B; S. Buddhan; R. Anandan; R. Sivakumar and R. AnbinEzhilan (2010). Antioxidant defense of betaine against isoprenaline - induced myocardial infarction in rats. Mol. Biol. Rep., 37(3):1319-27.

Hassan, R.A.; E.H. El-Ganzoury; F.A.Abd El-Ghany; and M.A. Shata,(2003). Influence of dietary zinc supplementation with methionine or phytase enzyme on productive and reproductive performance for Mandarahstrain. Egypt. Poult. Sci., 23:761-785.

Holsheimer.J.P. and W.M.M.A. Janssen, (1992). Limiting amino acids in low protein maize - soybean meal diets fed to broiler chicks from 3 to 7 weeks of age. Br. Poult. Sci., 32:141-158.

Keshavaraz, K. and R.E. Austic (2004). The use of low-protein, low-phosphorus, amino acid and phytase - supplemented diets on laying hens performance and nitrogen and phosphorus excretion. Poult. Sci., 83: 75-83.

Konca, Y.; F. Kirkpinar; S. Mert and E. Yaylak (2008).Effects of betaine on performance, carcass, bone and blood characteristics of broilers during natural summer temperatures.J. of Anim. And Vet. Adv., 7(8):930-937.

Naulia, A.H.; and M.A. Singh (2002).Effect of dietary protein and supplemental fat on performance of laying hens. Int. J. Poult. Sci., 4(12):1986-1989.

Park, J.H.; C.W. Kang and K.S. Ryu (2006).Effects of feeding betaine on performance and blood hormone in laying hens. Kor. J. Poult. Sci., 33:323-328.

Petronine, P.G.; E.M. Deangelis; A.F. Broghetti and K.P. Wheeler (1992).Modulation by betaine of cellular responses to osmotic stress. J. Biochem., 282:69-73.

Rath, N.C.; G.R. Huff; W.E. Huff and J.M. Balog (2000). Factors regulating bone maturity and strength in poultry. Poult. Sci., 79:1024-1032.

Rudolph M.C.; J.L. McManaman; T. Phang; T.Russell; D.J. Kominsky; N.J. Serkova; T. Stein; S.M. Anderson and M.C. Neville (2007). Metabolic regulation in the Lactating mammary gland: a lipid synthesizing machine. Physiol. Genomics, 28(3):323-36.

SAS (2002). SAS/STAT ® User's Guide: Statistics ver. 6.04, Fourth Edition SAS Institute Inc., Cary, $\mathrm{NC}$.

Seedor, J.G.; H.A. Quarruccio and D.D. Thompson (1991). The biophosphonate alendronate (MK-217) inhibits bone less due to ovariectomy in rats. J. of bone and Mineral Res., 6:339-346. 
Sinova, C.A.; E.J. Moreno; J.M.G. Abvarado; M. Frikha; R. Lázaro and G.G. Mateos (2010). Influence of source of soybean meal and lysine content of the diet on performance and total tract apparent retention of nutrition in broilers from 1 to 36 days of age. Poult. Sci., 89(7):1440-1450.

Tollba, A.A.H. and A.H. I. El-Nagar (2008).Increasing stocking density of Egyptian laying hens by using: 3-Increasing protein level and Betaine supplementation. Egypt. Poult. Sci., 28:745-766.

Xing J.L. Kang and Y. Jiang (2011).Effect of dietary betaine supplementation on lipogenesis gene expression and CPG methylation of lipoprotein lipase gene in broilers. Mol. Biol. Rep., 38(3):197581.

Zayed, S.M.A. (2012). Physiological studies on turkeys. M.Sc. Thesis, Fac. Agric., Mansoura Univ. Mansoura. Egypt.

Zhan, X.A. (2001). Effects of betaine on immune responses of Newcastle disease in broiler chicks.Chinese J. Vet. Sci., 21:99-102.

Zulkifli, L.; S.A. Mysahra and L.Z.Jin (2004).Dietary supplementation of betaine and response to high temperature stress in male broiler chicken. Asian- Aust. J. Anim., Sci., 17(2):244-249.

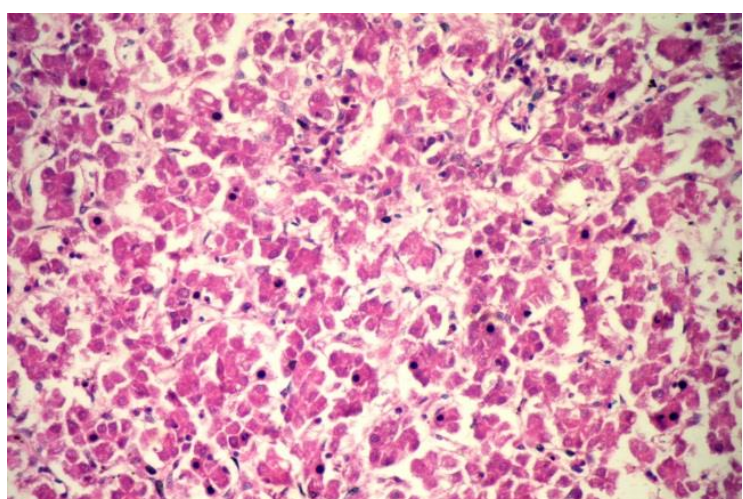

Figure 1

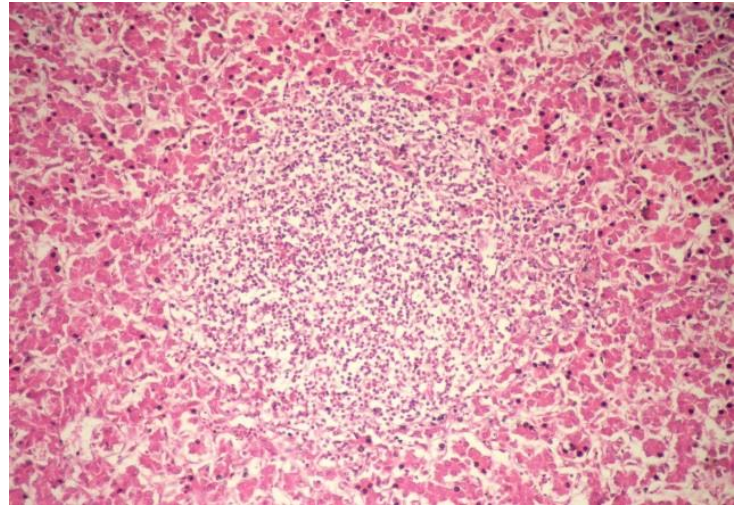

Figure 3

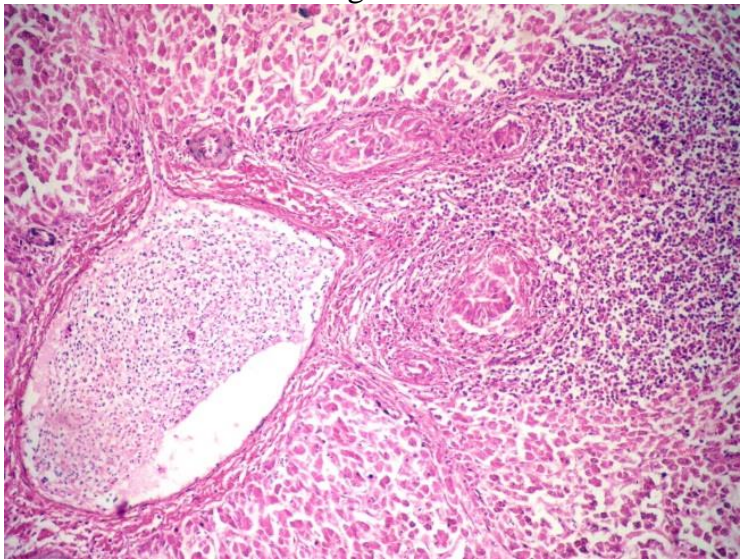

Figure 5

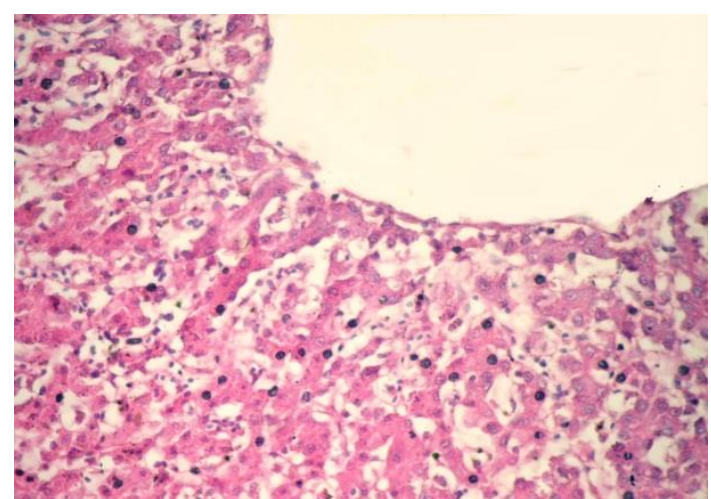

Figure 2

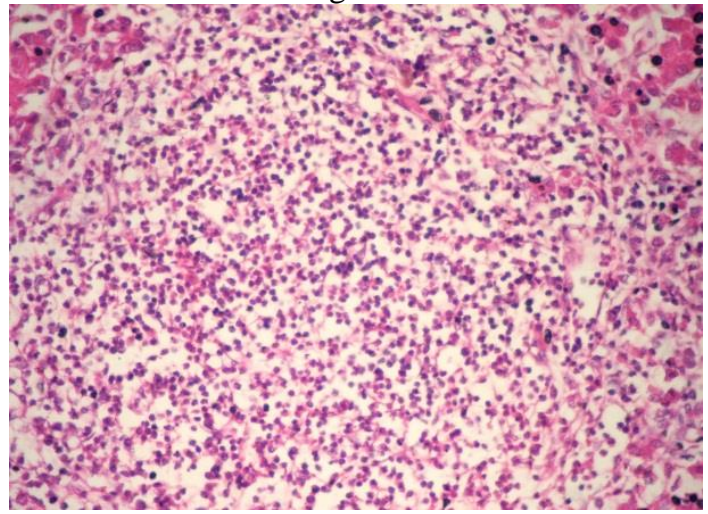

Figure 4

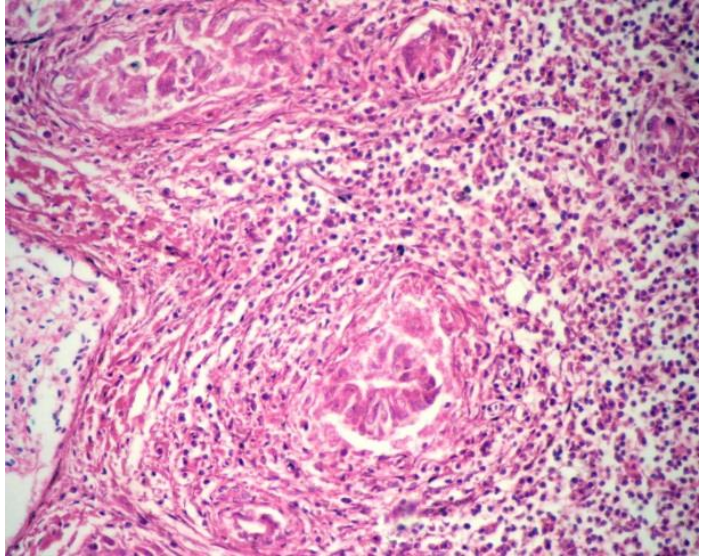

Figure 6

\section{T.s. of liver (H\& Ex 100).}



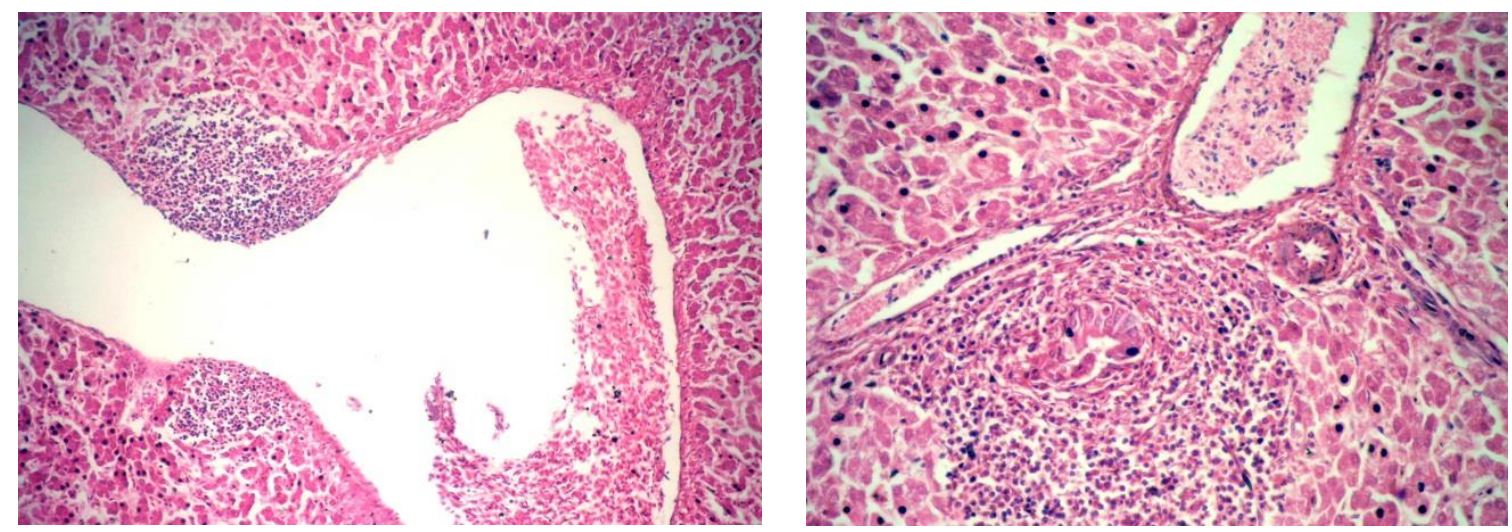

Figure 7

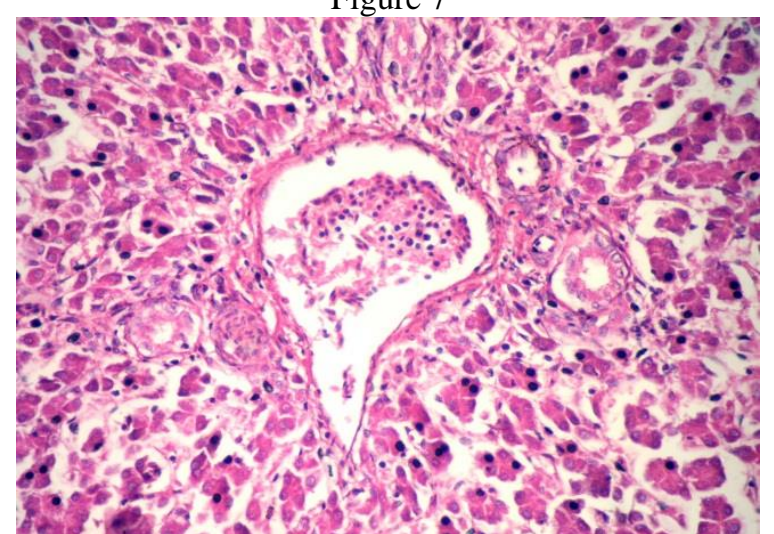

Figure 9

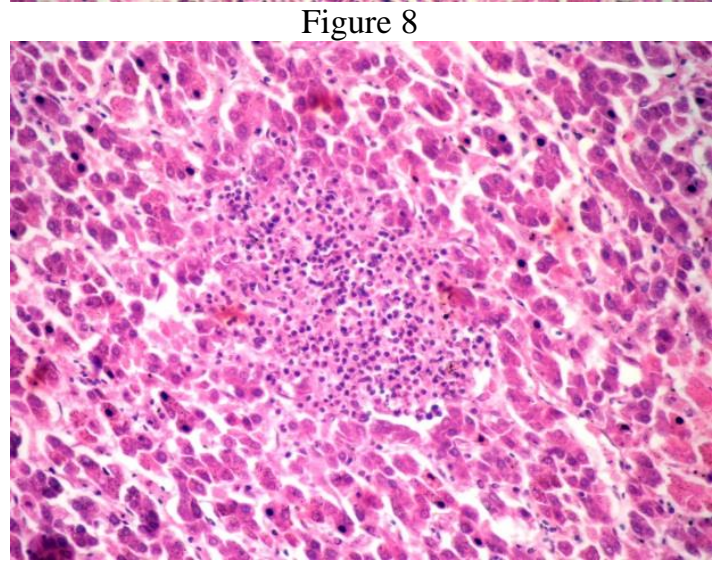

Figure 10

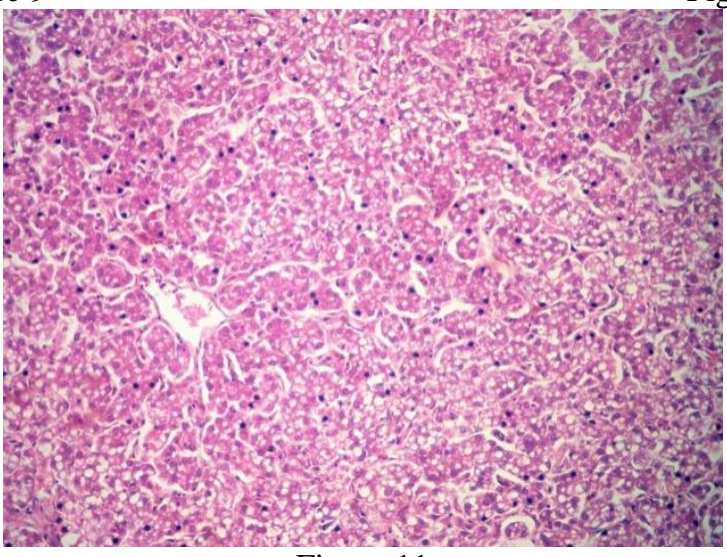

Figure 11

T.s. of liver (H\& Ex 100) 
Table (1). Composition and calculated chemical analysis of the starter and grower experimental basal diets

\begin{tabular}{|c|c|c|c|c|}
\hline \multirow{2}{*}{ Ingredients \% } & \multicolumn{2}{|c|}{ Starter (0-3 weeks) } & \multicolumn{2}{|c|}{ Grower (4-5 weeks) } \\
\hline & Control & $\mathrm{T}_{1}-\mathrm{T}_{5}$ diets* & Control & $\mathrm{T}_{1}-\mathrm{T}_{5}$ diets* \\
\hline Yellow corn & 46.45 & 54.44 & 54.44 & 60.0 \\
\hline Soybean meal (44\%) & 36.20 & 30.15 & 30.15 & 25.29 \\
\hline Full fat soya & 9.00 & 9.00 & 9.00 & 9.00 \\
\hline Soya + Sunflower oil & 3.65 & 2.00 & 2.00 & 1.5 \\
\hline Mono calcium phosphate & 1.85 & 1.68 & 1.68 & 1.68 \\
\hline Limestone & 1.60 & 1.48 & 1.48 & 1.48 \\
\hline Salt (Nacl) & 0.40 & 0.40 & 0.40 & 0.40 \\
\hline DL-Methionine & 0.34 & 0.20 & 0.20 & 0.12 \\
\hline L-Lysine HCL & 0.08 & 0.22 & 0.22 & 0.10 \\
\hline Vitamin \& Min. Mix $* *$ & 0.30 & 0.30 & 0.30 & 0.30 \\
\hline Choline chloride $50 \%$ & 0.13 & 0.13 & 0.13 & 0.13 \\
\hline Total & 100.00 & 100.00 & 100.00 & 100.00 \\
\hline \multicolumn{5}{|c|}{ Calculated chemical analysis $* * *$} \\
\hline Crude protein $\%$ & 22.93 & 20.93 & 20.93 & 19.06 \\
\hline $\mathrm{ME}(\mathrm{Kcal} / \mathrm{kg})$ & 3030 & 3029 & 3029 & 3055 \\
\hline Calcium $\%$ & 1.04 & 0.95 & 0.95 & 0.95 \\
\hline Available phosphorus $\%$ & 0.56 & 0.56 & 0.56 & 0.51 \\
\hline Lysine \% & 1.48 & 1.40 & 1.40 & 1.21 \\
\hline Methionine \% & 0.72 & 0.55 & 0.55 & 0.45 \\
\hline Methionine + cysteine $\%$ & 1.09 & 0.87 & 0.87 & 0.77 \\
\hline \multicolumn{5}{|c|}{ 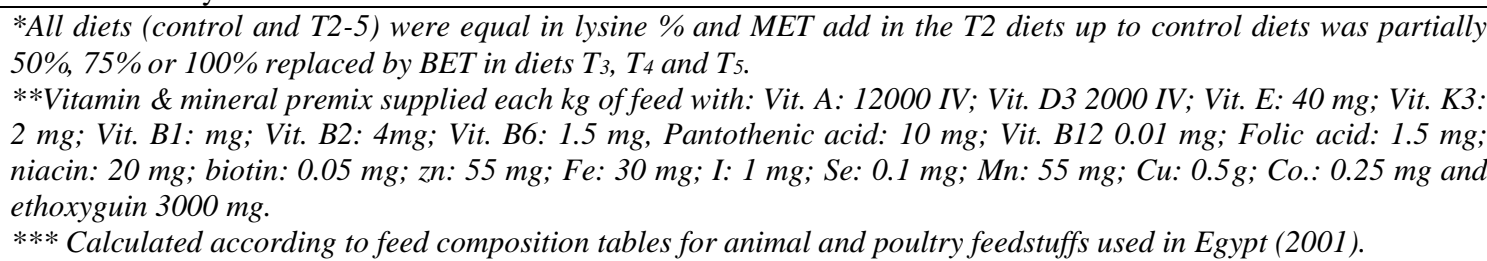 } \\
\hline
\end{tabular}

Table (2).Effect of feeding different experimental diets on some of bone measurements.

\begin{tabular}{lcccccccc}
\hline \multirow{2}{*}{ Items } & \multicolumn{9}{c}{ Dietary treatments } & \multirow{2}{*}{ SE } & \multirow{2}{*}{ Sig. } \\
\cline { 2 - 7 } & control & $\mathrm{T}_{1}$ & $\mathrm{~T}_{2}$ & $\mathrm{~T}_{3}$ & $\mathrm{~T}_{4}$ & $\mathrm{~T}_{5}$ & & \\
\hline Wet tibia weight $(\mathrm{g})$ & 10.61 & 10.59 & 9.37 & 9.54 & 10.64 & 9.57 & 0.7 & $\mathrm{NS}$ \\
Tibia length (mm) & $8.53^{\mathrm{a}}$ & $8.40^{\mathrm{ab}}$ & $7.93^{\mathrm{b}}$ & $8.33^{\mathrm{ab}}$ & $8.47^{\mathrm{ab}}$ & $8.30^{\mathrm{ab}}$ & 0.16 & $*$ \\
Tibia width (mm) & 0.63 & 0.62 & 0.63 & 0.62 & 0.58 & 0.57 & 0.03 & $\mathrm{NS}$ \\
Tibia seedor index (SI) & 0.61 & 0.60 & 0.59 & 0.59 & 0.62 & 0.59 & 0.04 & $\mathrm{NS}$ \\
\hline
\end{tabular}

$a, b$ Means in the same raw with different superscripts are significantly $(P \leq 0.05)$ different.

N.S.: non-significant

Table (3).Effect of feeding different experimental diets on some plasma parameters.

\begin{tabular}{lcccccccc}
\hline \multirow{2}{*}{ Items } & \multicolumn{9}{c}{ Dietary treatments } & \multirow{2}{*}{ SE } & \multirow{2}{*}{ Sig. } \\
\cline { 2 - 6 } & Control & $\mathrm{T} 1$ & $\mathrm{~T} 2$ & $\mathrm{~T} 3$ & $\mathrm{~T} 4$ & $\mathrm{~T} 5$ & & \\
\hline Total protein $(\mathrm{g} / \mathrm{dl})$ & 6.72 & 7.75 & 6.08 & 6.63 & 5.95 & 5.93 & 0.54 & $\mathrm{NS}$ \\
Albumin (g/dl) & 3.99 & 3.94 & 4.02 & 4.09 & 4.08 & 3.87 & 0.13 & $\mathrm{NS}$ \\
Globulin (g/dl) & 2.73 & 3.80 & 2.06 & 2.54 & 1.87 & 2.06 & 0.51 & $\mathrm{NS}$ \\
*A/G ratio & 1.46 & 1.04 & 1.95 & 1.61 & 2.18 & 1.88 & 0.44 & $\mathrm{NS}$ \\
Uric acid (mg/dl) & 3.87 & 3.55 & 3.80 & 4.60 & 5.16 & 6.46 & 0.97 & $\mathrm{NS}$ \\
Total lipids (mg/dl) & 428.23 & 497.03 & 416.37 & 461.44 & 332.14 & 574.14 & 95.88 & $\mathrm{NS}$ \\
Triglcerides (mg/dl) & 83.33 & 60.66 & 68.33 & 88.00 & 66.33 & 81.33 & 6.00 & $\mathrm{NS}$ \\
Cholesterol (mg/dl) & 183.50 & 210.23 & 182.43 & 206.30 & 180.16 & 175.83 & 21.63 & $\mathrm{NS}$ \\
AST (RFU/ml) & $27.50^{\mathrm{ab}}$ & $41.00^{\mathrm{a}}$ & $26.07^{\mathrm{ab}}$ & $27.65^{\mathrm{ab}}$ & $21.50^{\mathrm{b}}$ & $36.66^{\mathrm{ab}}$ & 4.75 & $*$ \\
ALT (RFU/ml) & 15.11 & 18.04 & 12.86 & 14.98 & 14.18 & 12.86 & 1.34 & $\mathrm{NS}$ \\
\hline
\end{tabular}

$a, b$ Means in the same raw with different superscripts are significantly $(P \leq 0.05)$ different.

N.S.: non-significant 
Table (4). Effect of different treatments on the fatty acids differentiation.

\begin{tabular}{lcccccc}
\hline \multirow{2}{*}{ Fatty acids } & \multicolumn{7}{c}{ Different } & treatments \\
\cline { 2 - 7 } & Control & T1 & T2 & T3 & T4 & T5 \\
\hline Caprlyic acid C8 & 1.099 & 0.726 & 2.549 & 2.071 & 1.160 & 1.536 \\
Myristic acid C14 & 0.478 & 0.517 & 0.495 & 0.533 & 0.548 & 0.491 \\
Palmitic acid C16 & 25.919 & 25.423 & 25.952 & 26.424 & 25.004 & 25.168 \\
Palmitioleic acid C16:1 & 3.571 & 4.183 & 3.589 & 3.225 & 3.752 & 3.899 \\
Heptadecanoic acid C17 & 0.142 & 0.128 & 0.183 & 0.124 & 0.156 & 0.147 \\
Strearic acid C18 & 6.557 & 6.407 & 6.789 & 7.703 & 6.679 & 6.261 \\
Oleic acid C18.1 & 2.338 & 39.167 & 36.224 & 35.302 & 35.719 & 32.114 \\
Linoleic acid C18.2 & 16.631 & 19.119 & 16.303 & 17.044 & 19.312 & 18.581 \\
Linolenic acid C 18.3 & 0.674 & 0.775 & 0.691 & 0.711 & 0.813 & 0.841 \\
Behenic C22 & 0.151 & 0.108 & 0.164 & 0.176 & 0.181 & 0.244 \\
Ermcic C22:1 & 0.183 & - & 0.197 & 0.199 & 0.215 & 0.233 \\
Sat/unsat ratio\% & 1.47 & 0.53 & 0.63 & 0.66 & 0.56 & 0.61 \\
\hline
\end{tabular}

تأثير إضافة الميثيونين و/أو البيتايين إلى علائق منخفضة البروتين على: 2- قياسات العضم - صفات الام ـ اختبارات هستولوجية لبدارى التسمين

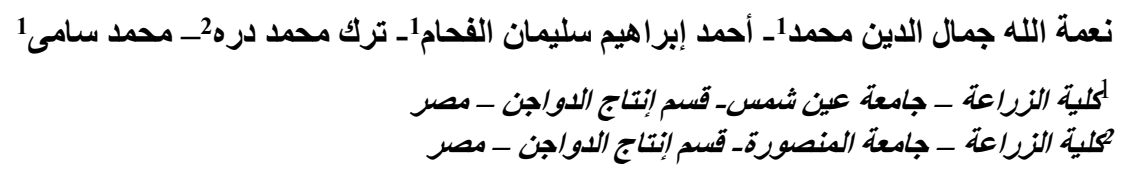

تهدف الدراسة إلى تقييم تأثير استخدام كلاً من الميثيونين و /أو البيتايين على قياسات العظم وبعض التأثيرات الفسيولوجية المتعلقة

بالدم لبدارى التسمين المغذاة على علائق منخفضية البروتين.

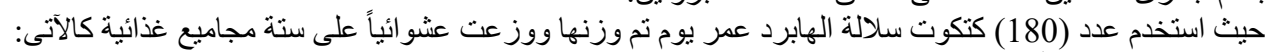

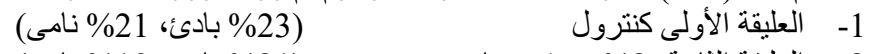

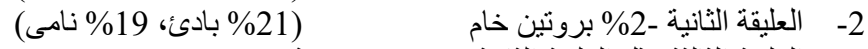

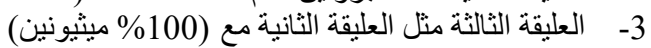

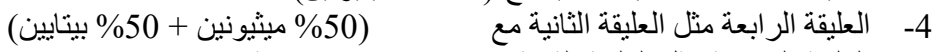

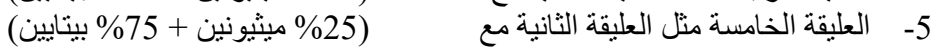

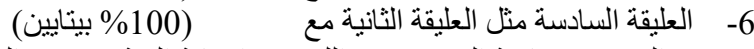
جميع العلائق منساوية المحتوى فى الليسين وإضافة الهيثئيونين في العليقة الثانية حتى مستوى الكنترول (العليقة الأولى).

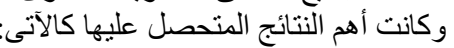

1- - طول عظمة الساق تأثرت معنوياً بالمعاملات الغذائية وسجلت الكتاكيت المغذاة على العليقة الثالثة أقل القيم بالمقارنة بالكنترول.

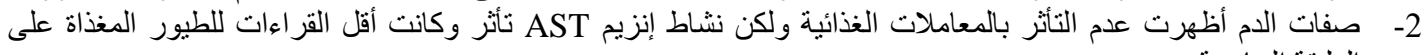

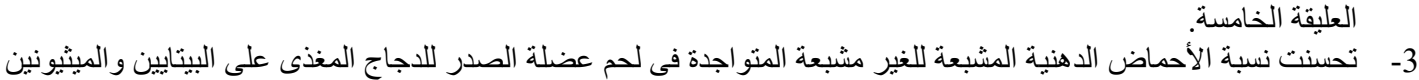

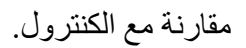

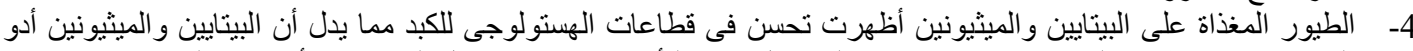

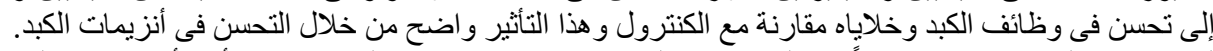

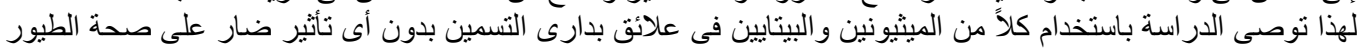
بل العكس أدى إلى تحسين واضح من خلال تحاليل الدم وقطاعات الهنتولو في للكبد. 